\title{
Untargeted Metabolomics of Fermented Rice Using UHPLC Q-TOF MS/MS Reveals an Abundance of Potential Antihypertensive Compounds
}

\author{
Eric Banan-Mwine Daliri ${ }^{1}{ }^{(\mathbb{D},}$, Fred Kwame Ofosu ${ }^{1}$, Ramachandran Chelliah ${ }^{1}$, \\ Joong-Hark Kim ${ }^{2,3}$, Jong-Rae Kim ${ }^{1,4}$, Daesang Yoo ${ }^{1,5}$ and Deog-Hwan Oh ${ }^{1, *}$ \\ 1 Department of Food Science and Biotechnology, College of Agriculture and Life Sciences, \\ Kangwon National University, Chuncheon 24341, Gangwon-do, Korea; ericdaliri@yahoo.com (E.B.-M.D.); \\ fkofosu@gmail.com (F.K.O.); ramachandran@gmail.com (R.C.); jrkim@gmail.com (J.-R.K.); \\ dsyoo@yahoo.com (D.Y.) \\ 2 Department of Medical Biotechnology, College of Biomedical Sciences, Kangwon National University, \\ Chuncheon 24341, Gangwon-do, Korea; jhk@yahoo.com \\ 3 R\&D, Erom, Co., Ltd., Chuncheon 24427, Gangwon-do, Korea \\ 4 R\&D, Hanmi Natural Nutrition Co., LTD 44-20, Tongil-ro 1888 beon-gil, Munsan, \\ Paju 10808, Gyeonggi, Korea \\ 5 R\&D, H-FOOD, 108-66, 390 gil, Jingun Oh Nam-Ro, Nam Yang, Ju-Shi 12041, Gyung Gi-Do, Korea \\ * Correspondence: deoghwa@kangwon.ac.kr
}

Received: 3 July 2020; Accepted: 24 July 2020; Published: 27 July 2020

\begin{abstract}
Enzyme treatment and fermentation of cereals are known processes that enhance the release of bound bioactive compounds to make them available for bioactivity. In this study, we tested the angiotensin converting enzyme (ACE) inhibitory ability of destarched rice, Prozyme 2000p treated destarched rice (DP), and fermented DP samples. Prozyme 2000p treatment increased the ACE inhibitory ability from $15 \pm 5 \%$ to $45 \pm 3 \%$. Fermentation of the Prozyme 2000p treated samples with Enterococcus faecium EBD1 significantly increased the ACE inhibitory ability to $75 \pm 5 \%$, while captopril showed an ACE inhibition of $92 \pm 4 \%$. An untargeted metabolomics approach using Ultra-high-performance liquid tandem chromatography quadrupole time of flight mass spectrometry revealed the abundance of vitamins, phenolic compounds, antioxidant peptides, DPP IV inhibitory peptides, and antihypertensive peptides in the fermented samples which may account for its strong ACE inhibition. Although fermented DP had decreased fatty acid levels, the amount of essential amino acid improved drastically compared to destarched rice. Our results show that fermenting Prozyme-treated destarched rice with Enterococcus faecium EBD1 generates abundant bioactive compounds necessary for developing antihypertensive functional foods.
\end{abstract}

Keywords: bioactive peptides; hypertension; phenolic compounds; functional food

\section{Introduction}

In recent years, cereal grains such as rice have attracted much scientific attention [1] because they contain phenolic compounds such as quercetin, ferulic acid, and salicylic acid [2] which have strong antioxidant abilities [3]. Over the years, oxidative stress has been shown to play a key role in the pathogenesis of hypertension $[4,5]$ since reactive oxygen species can cause endothelial dysfunction [6] leading to arterial stiffness in humans [7,8]. One popular physiological mechanism of hypertension is the renin-aldosterone-angiotensin system (RAAS) [9]. In the RAAS, renin cleaves angiotensinogen to release angiotensin I which is then hydrolyzed by angiotensin 1-converting enzyme (ACE) to generate angiotensin II (a vasoconstrictor) [10]. Interestingly, phenolic compounds have 
been shown to strongly inhibit angiotensin 1-converting enzyme (ACE) [11,12] and the strength of inhibition is directly proportional to the number of hydroxyl groups they possess [13]. In addition to polyphenols, rice contains proteins which when hydrolyzed, generate bioactive peptides [10]. Many potent antihypertensive peptides such as IHRF [14], VNP, and VWP [15] have been identified in rice. These peptides may reduce hypertension by inhibiting ACE and/or renin activities [16], triggering nitric oxide production, or blocking angiotensin II receptors [17]. Antihypertensive peptides are usually generated in foods either by enzyme hydrolysis or fermentation of protein samples. Lactic acid bacteria have been effective in fermenting food materials to release polyphenols [18] and to generate antihypertensive peptides [19]. In recent years, metabolomic techniques such as ${ }^{1} \mathrm{H}-\mathrm{NMR}$ $\left({ }^{1} \mathrm{H}\right.$-nuclear magnetic resonance), GC-MS (gas chromatography-mass spectrometry), and LC-MS (liquid chromatography-mass spectrometry) have been used to identify metabolites in foods [20]. Among the techniques commonly used, LC-MS is the most used in metabolomic studies due to its detection sensitivity, high resolution, and nonderivatization of samples [21]. Ultra-high-performance liquid tandem chromatography quadrupole time of flight mass spectrometry (UHPLC-QTOF/MS) is a new approach in chromatography and was developed based on LC-MS to determine and quantify more metabolites [22]. In this study, we determined the ACE inhibitory ability of destarched rice before and after Prozyme 2000p treatment and after fermentation. We then used UHPLC-QTOF/MS to analyze the metabolite changes that occurred after Prozyme 2000p treatment and after fermentation to identify bioactive compounds generated by the processing methods.

\section{Materials and Methods}

\subsection{Chemicals and Cultures}

All chemical reagents were of analytical grade. ACE-1 Assay Kit (Fluorometric) was purchased from Biovision (Milpitas, CA 95035, USA). All other reagents, unless specified, were purchased from Sigma-Aldrich, Seoul, Korea. Two rice powder samples (Oriza sativa L. variety Japonica) were received from Erom Company Limited (Chuncheon-si, Kangwon-do, Korea). One sample (destarched rice) was composed of rice powder treated with $\alpha$-amylase to hydrolyze the starch present. The second sample (destarched rice + Prozyme (DP)) consisted of destarched rice treated with Prozyme 2000p.

Enterococcus faecium EBD1 was obtained from the Department of Food Science and Biotechnology, Kangwon National University, Korea to be used for fermentation. This bacterium was used in the current study because it demonstrated strong proteolytic ability in our previous study (data not shown). The bacteria stock culture was stored at $-80^{\circ} \mathrm{C}$ in de Man, Rogosa and Sharpe (MRS) broth (Difco), containing $20 \%$ glycerol $(v / v)$. The bacterium was spread on MRS agar and incubated at $37^{\circ} \mathrm{C}$ overnight to obtain single colonies. MRS broth $(10 \mathrm{~mL})$ was then inoculated with a single bacteria colony and incubated at $37^{\circ} \mathrm{C}$. The cells were harvested at the exponential phase of growth. The number of viable bacterial cells was determined by the plate count on MRS agar.

\subsection{Rice Fermentation}

The bacteria growth medium for the lactic acid bacteria consisted of $10 \%(w / v)$ Prozyme 2000p treated destarched rice powder in distilled water. The growth media was sterilized by autoclaving at $121{ }^{\circ} \mathrm{C}$ for $15 \mathrm{~min}$ before inoculating with lactic acid bacteria. E. faecium EBD1 $\left(2 \times 10^{8} \mathrm{cfu} / \mathrm{mL}\right)$ was transferred from an overnight culture to a $200 \mathrm{~mL}$ of autoclaved growth media (pH6). The media was incubated at $37^{\circ} \mathrm{C}$ with $150 \mathrm{rpm}$ agitation for $48 \mathrm{~h}$. The media was then centrifuged at $10,000 \times g$ for $10 \mathrm{~min}$ and the supernatant was freeze-dried using TFD5505 table top freeze dryer (ilshinBioBase Co. Ltd., Gyeonggi-do, Korea) and the dried samples were stored at $-20{ }^{\circ} \mathrm{C}$ for further analysis. The final fermented product was labelled as Fermented DP. 


\subsection{Determination of Angiotensin 1-Converting Enzyme Inhibitory Ability}

ACE inhibitory activities of destarched rice, Prozyme treated distarched rice (DP), and fermented Prozyme-treated rice (fermented DP) powder were measured using an ACE-1 Assay Kit according to the manufacture's instructing with some modifications (Table S1). Briefly, $10 \mu \mathrm{L}$ of diluted ACE-1 solution was transferred to a 96 well plate and the volume was adjusted to $50 \mu \mathrm{L} /$ well with ACE- 1 assay buffer. An aliquot of the rice samples $(20 \mu \mathrm{L}, 5 \mathrm{mg} / \mathrm{mL})$ was added to the wells and mixed thoroughly. Captopril $(20 \mu \mathrm{L}, 5 \mathrm{mg} / \mathrm{mL})$ was used as a positive control. ACE-1 substrate $(50 \mu \mathrm{L})$ was added to the wells and mixed. Fluorescence $(\mathrm{Ex} / \mathrm{Em}=330 / 430 \mathrm{~nm})$ was measured in a kinetic mode for $2 \mathrm{~h}$ at $37^{\circ} \mathrm{C}$. A standard curve was prepared using the Abz-standard solution. The ACE1 activity was calculated as:

$\mathrm{ACE} 1$ activity $=\mathrm{B} \times \mathrm{D} /(\Delta \mathrm{T} \times \mathrm{P})=\mathrm{pmol} / \mathrm{minute} / \mathrm{mg}$,

where:

$$
\begin{gathered}
\mathrm{B}=\mathrm{Abz} \text { in sample based on standard curve slope (pmol), } \\
\Delta \mathrm{T}=\text { reaction time (minutes), } \\
\mathrm{P}=\text { sample used into the reaction well (in } \mathrm{mg}), \\
\mathrm{D}=\text { sample dilution factor. }
\end{gathered}
$$

One unit of ACE- 1 activity is the amount of enzyme that catalyzes the release of $1 \mathrm{nmol}$ of Abz per min from the substrate under the assay conditions at $37^{\circ} \mathrm{C}$. The extent of inhibition was calculated as $100 \% \times[(B-A) / B]$ where $A$ is the ACE-1 activity in the presence of $A C E$ and $A C E$ inhibitor, $B$ is the ACE-1 activity without ACE inhibitory component.

\subsection{Metabolomics Analysis}

Each rice sample $(1 \mathrm{~g})$ was extracted with $20 \mathrm{~mL}$ of $50 \%$ methanol and placed on a mini rocker (Clinical Diagnostics, Gangnam, Korea) overnight. The samples were mixed completely for $30 \mathrm{~s}$ using a vortex and subsequently centrifuged at $12,000 \times g$ for $12 \mathrm{~min}$ at $4{ }^{\circ} \mathrm{C}$. Aliquots $(1 \mathrm{~mL})$ of the supernatants were filtered through $0.25 \mu \mathrm{m}$ pore size Millex syringe filters (Merck KGaA, Darmstadt, Germany) and transferred into LC-MS vials. LC-MS/MS analysis was carried out using a UHPLC (SCIEX ExionLC AD system, Framingham, MA, USA) connected to a controller, a pump, a degasser, an autosampler, column oven, and a photodiode array detector (ExionLC) coupled to a quadrupole time-of-flight mass spectrometer (Q-TOF-MS) (X500R QTOF). The analytical column used was a $100 \times 3 \mathrm{~mm}$, Accucore C18 column (Thermo Fisher Scientific, Waltham, MA, USA). Solvent A consisted of water with $0.1 \%$ formic acid and solvent $B$ was methanol. The chromatography was carried at a flow rate of $0.4 \mathrm{~mL} / \mathrm{min}$. A linear gradient was programmed for $25 \mathrm{~min}$ as follows: $0-3.81 \mathrm{~min}, 9 \%$ to $14 \% \mathrm{~B} ; 3.81-4.85 \mathrm{~min}$, $14 \%$ to $15 \% \mathrm{~B} ; 4.85-5.89 \mathrm{~min}, 15 \% \mathrm{~B} ; 5.89-8.32 \mathrm{~min}, 15 \%$ to $17 \% \mathrm{~B} ; 8.32-9.71 \mathrm{~min}, 17 \%$ to $19 \% \mathrm{~B}$; 9.71-10.40 $\mathrm{min}, 19 \% \mathrm{~B} ; 10.40-12.48 \mathrm{~min}, 19 \%$ to $26 \% \mathrm{~B} ; 12.48-13.17 \mathrm{~min}, 26 \%$ to $28 \% \mathrm{~B} ; 13.17-14.21$ $\mathrm{min}, 28 \%$ to $35 \% \mathrm{~B} ; 14.21-15.95 \mathrm{~min}, 35 \%$ to $40 \% \mathrm{~B} ; 15.95-16.64 \mathrm{~min}, 40 \%$ to $48 \% \mathrm{~B} ; 16.64-18.37 \mathrm{~min}$, $48 \%$ to $53 \% \mathrm{~B} ; 18.37-22.53 \mathrm{~min}, 53 \%$ to $70 \% \mathrm{~B} ; 22.53-22.88 \mathrm{~min}, 70 \%$ to $9 \% \mathrm{~B} ; 22.88-25.00 \mathrm{~min}, 9 \% \mathrm{~B}$. The injection volume was $5 \mu \mathrm{L}$. The Q-TOF-MS was set for the negative mode through a mass range of 100-1000 and a resolution of 5000. The capillary and cone voltages used to record full mass spectra were $1.45 \mathrm{kV}$ and $30 \mathrm{~V}$, respectively. The flow rate of Helium (the cone gas) was $45 \mathrm{~L} / \mathrm{h}$, while the flow rate of the desolvation gas $\left(\mathrm{N}_{2}\right)$ was $900 \mathrm{~L} / \mathrm{h}$. The temperature of $\mathrm{N}_{2}$ was $250{ }^{\circ} \mathrm{C}$, the ion source temperature was $120^{\circ} \mathrm{C}$, while the collision energies needed to obtain the MS/MS spectra were set at 15,20 , and $30 \mathrm{~V}$.

\subsection{Data Analysis}

All data were obtained and processed using SCIEX OS 1.0 software. A non-target algorithm was used for peak finding. Matrix and sample specific signals were separated from true contaminations 
using an automatic sample-control comparison algorithm. Compound identification was done by using empirical formula finding, MS/MS library searching, and online database searching. Compound names, peak area, retention time, similarity to metabolites in the database, and mass $(\mathrm{m} / \mathrm{z})$ were ultimately imported into Microsoft Excel.

\subsection{Statistical Analysis}

For ACE inhibitory ability tests, all experiments were carried out in triplicates and the results were expressed as mean \pm standard deviation. The statistical analysis of data was performed using GraphPad Prism 5.0 (2007) statistical software system (GraphPad Software Inc., San Diego, CA 92037 USA). $p<0.05$ was considered significant as evaluated by Student's $t$-test.

ClustVis software (http://biit.cs.ut.ee/clustvis/) was used in multivariate statistical analyses, including principal component analysis (PCA) and heat maps [23]. PCA was performed to visualize the changes in metabolite composition in destarched rice, Prozyme treated destarched rice (DP), and fermented DP. Heat maps and PCA plots were drawn by using identified compounds and their peak area. We used peak areas because it is widely accepted that the peak area of an analyte in a chromatograph is directly proportional to its concentration [24-26].

\section{Results and Discussion}

Rice consists of about $90 \%$ carbohydrate, up to $8 \%$ protein, and about $2 \%$ fat [27]. These major components are bound together in the food matrix and hence, hydrolyzing rice starch with $\alpha$-amylase enables the release of bound proteins and other biomolecules from the food matrix, making them available for subsequent reactions.

\subsection{ACE Inhibitory Activity of Rice Samples}

Prozyme treatment significantly $(p<0.05)$ increased the ACE inhibitory ability of destarched rice from $15 \pm 5 \%$ to $45 \pm 3 \%$ (Figure 1). This could be due to the release of ACE inhibitory compounds from the rice proteins during Prozyme proteolysis. Our observation agrees with earlier studies that showed that hydrolysis of rice proteins enhances the generation of ACE inhibitory hydrolysates [28]. Subsequent fermentation of the Prozyme hydrolysate with E. faecium EBD1 further increased the inhibitory effect up to $75 \pm 5 \%$, while Captopril (a standard ACE inhibitory peptide) demonstrated a $92 \pm 4 \%$ inhibitory ability.

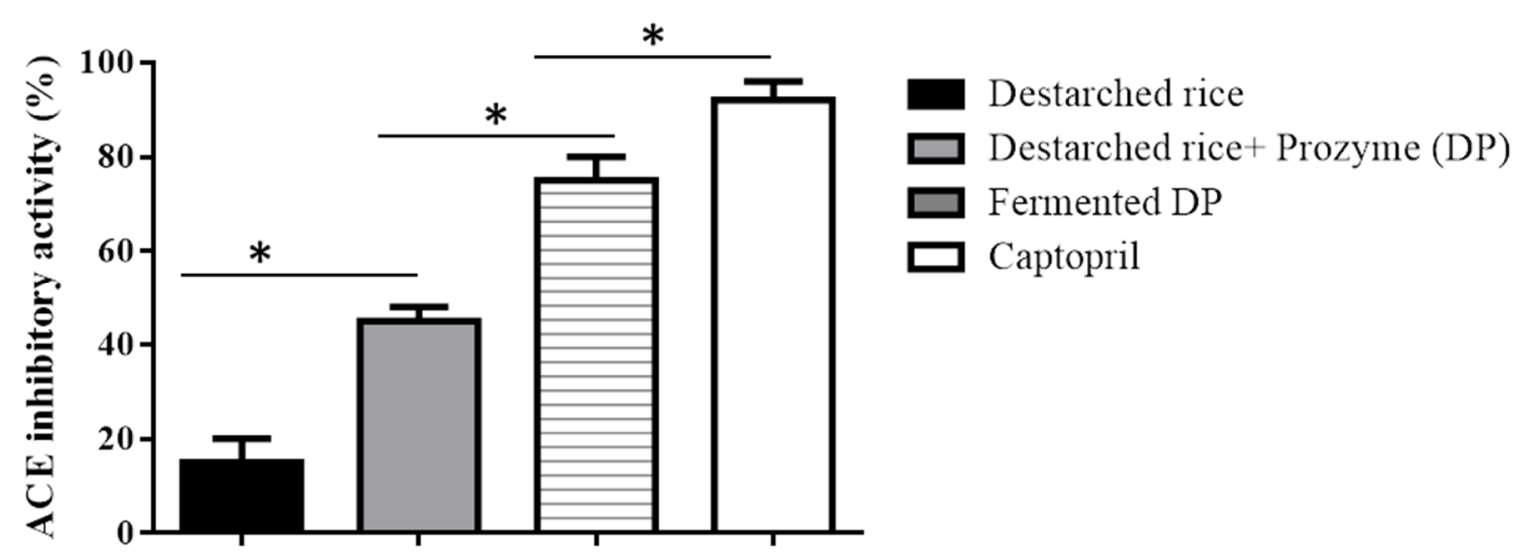

Figure 1. ACE inhibitory activities of destarched rice, Prozyme treated destarched rice (DP), and fermented DP. Data show mean SD $(n=3)$. Each bar represents the means of three replicates \pm S.D.

* denotes a significant difference between the ACE inhibitory ability of the samples.

During lactic acid bacteria fermentation, a number of organic acids are generated from the sugars and lipids available in the growth media and this affects the flavor and $\mathrm{pH}$ of the final product [29]. 
ACE activity is best at a $\mathrm{pH}$ of $~ 8.3$ [11] and hence, the increased acidity of fermented food may contribute to inhibition of the enzyme. In this study, a total of twenty organic acids were detected in all the rice samples (Figure 2A). Ten organic acids were detected in destarched rice, 14 in DP, and 19 in fermented DP (Table S2). Only the fermented samples contained homocitric acid, citric acid, binicotinic acid, dioxoheptanoic acid, oxobutyric acid, and hydroxybutanoic acid. Meanwhile, butyric acid [30], nicotinic acid [31], and citric acid are known antihypertensive compounds and hence, their enrichment in the fermentate makes it a potential antihypertensive functional food. Although the types and levels of organic acids in the three samples were different (Figure 2B), organic acid profiles of destarched rice and DP were similar (Figure 2C).
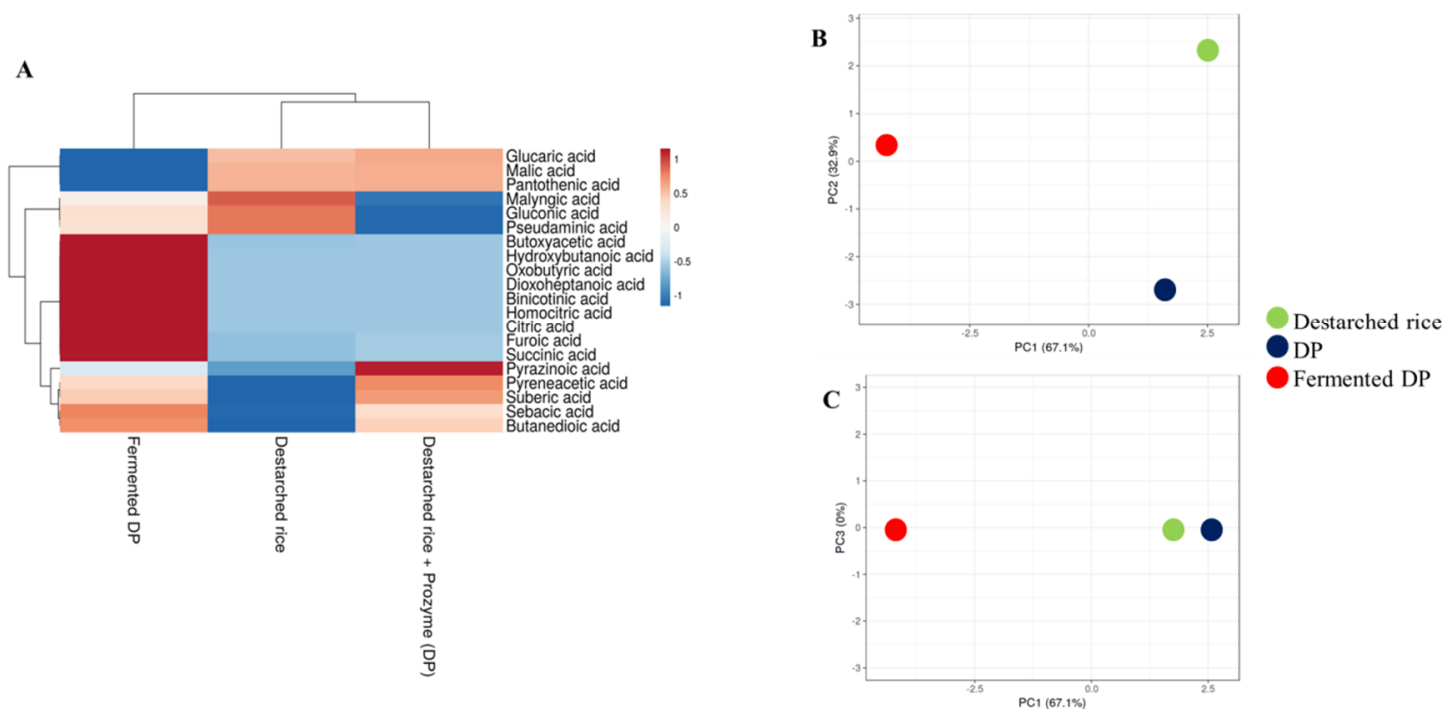

Figure 2. Relative levels of organic acids and volatile compounds in destarched rice, Prozyme treated destarched rice (DP), and fermented DP. (A) Heat map shows the different levels of organic acids present in the three samples. The color range from red to blue represents higher to lower levels of organic acids. (B,C) are principal component analysis (PCA) plots. (B) consists of PC1 and PC2, while (C) consists of PC1 and PC3. Red circles represent fermented DP, black represents Prozyme treated destarched rice (DP), and green represents destarched rice samples.

\subsection{Amino Acid Levels in the Rice Samples}

A total of sixteen amino acids were detected in the analyzed samples (Figure 3A, Table S3). In this study, destarched rice contained the least free amino acids contents since most of the amino acids might have remained bound to their parent proteins. Hydrolysis of rice proteins with Prozyme resulted in the cleavage and release of high amounts of essential amino acids such as phenylalanine, threonine, methionine, histidine, and tryptophan (Figure 3). The levels of these essential amino acids reduced drastically after fermentation except for histidine and methionine. Glutamine, cysteic acid, tryptophan, and pyroglutamic acid, though present in the Prozyme treated sample, were not detected in the fermented sample (Table S3) probably because they were consumed by the bacteria to meet their nitrogen requirements during the fermentation process. Meanwhile, the level of leucine (an essential amino acid) and some conditionally essential amino acids such as ornithine, arginine, and serine were increased after fermentation (Figure 3). As shown in the PCA plot (Figure 3B), the amino acid profiles of DP were similar to those of fermented DP but different from destarched rice (Figure 3C).

\subsection{E. faecium EBD1fermentation Increases the Amount of Phenolic Compounds in Rice}

Recent studies have shown that a strong hydrophobic interaction exists between phenolic compounds and other rice components [32]. In this study, 10 out of the 17 detected phenolic compounds were present in destarched rice, while 9 were detected after Prozyme treatment (Figure 4, Table S4). 
In the fermented samples however, 16 phenolic compounds were present and this implies that the fermentation process effectively enhanced the liberation of phenolic compounds that remained bound to the rice matrix even after $\alpha$-amylase and Prozyme treatments. Fermentation resulted in the enrichment of strong antioxidant and antihypertensive phenolic compounds such as vanillic acid [33], eugenol [34], veratric acid [35], ethyl gallate [36], epigallocatechin [37], apigenin [38], and chrysophanol [39]. Our observation agrees with an earlier study that demonstrated that microbial fermentation increases the polyphenol contents of cereals $[40,41]$.
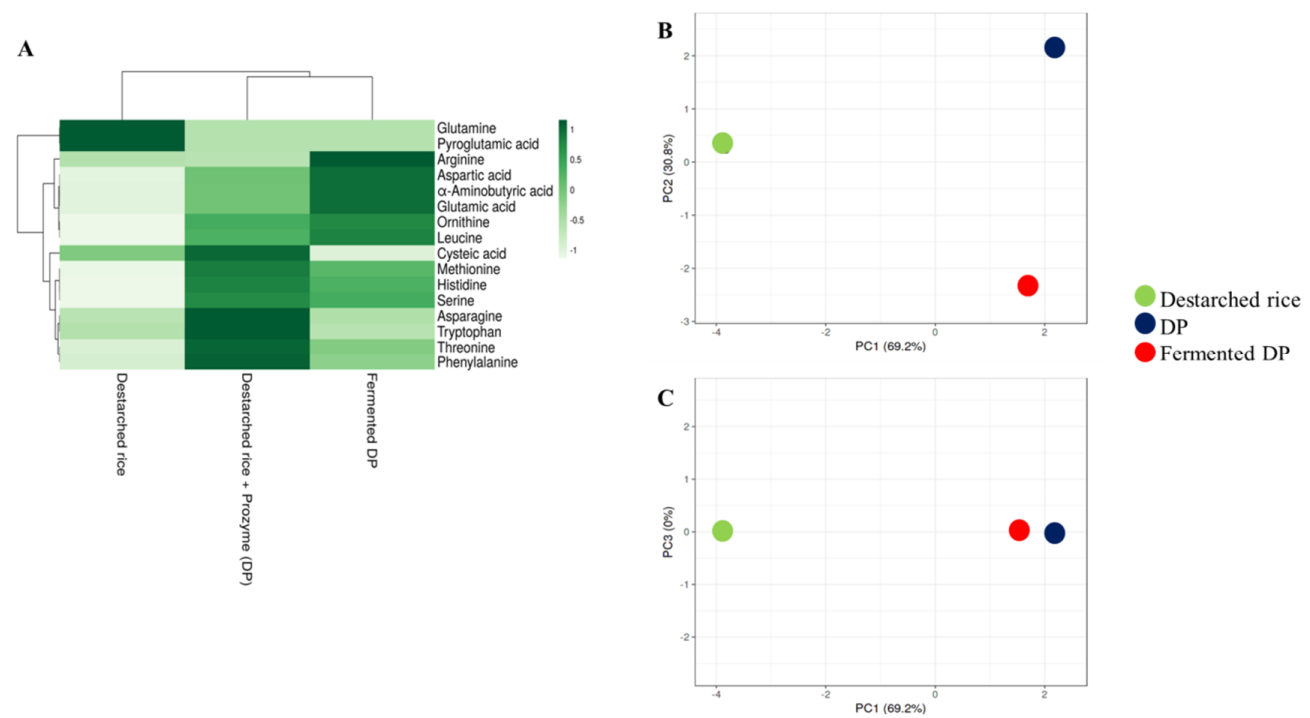

Figure 3. Relative levels of amino acids in destarched rice, Prozyme treated destarched rice (DP), and fermented DP. (A) Heat map shows the different levels of organic acids present in the three samples. The color range from green to white represents higher to lower levels of amino acids. (B,C) are principal component analysis (PCA) plots. (B) consists of PC1 and PC2, while (C) consists of PC1 and PC3. Red circles represent fermented DP, black represents Prozyme treated destarched rice (DP), and green represents destarched rice samples.
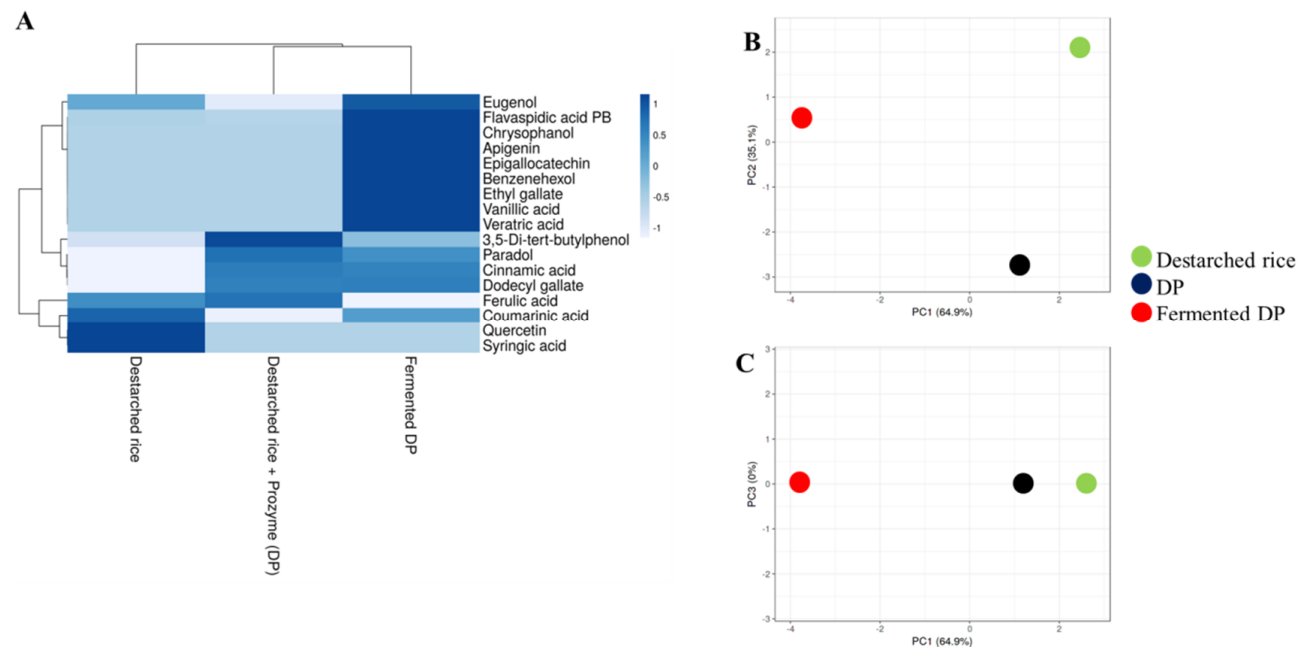

Figure 4. Relative levels of phenolic compounds in destarched rice, Prozyme treated destarched (DP), and fermented DP. (A) Heat map shows the different levels of phenolic compounds present in the three samples. The color range from blue to white represents higher to lower levels of phenolic compounds. $(\mathbf{B}, \mathbf{C})$ are principal component analysis (PCA) plots. (B) consists of PC1 and PC2, while (C) consists of PC1 and PC3. Red circles represent fermented DP, black represents Prozyme treated destarched rice (DP), and green represents destarched rice samples. 


\subsection{E. faecium EBD1fermentation Reduces Lipid Levels in Rice}

Oxidation of lipids during fermentation results in the generation volatile compounds such as aldehydes and alcohols which contribute to flavor [42]. In this study, E. faecium EBD1fermentation caused a general reduction in the fatty acid levels in the rice sample (Figure 5). The levels of stearic acid (an antioxidant fatty acid) [43] slightly increased, while lauric acid (an antihypertensive fatty acid) [44] was still detectable in the fermentate. Our results are different from an earlier study which found no significant changes in lipid content during millet fermentation [45].

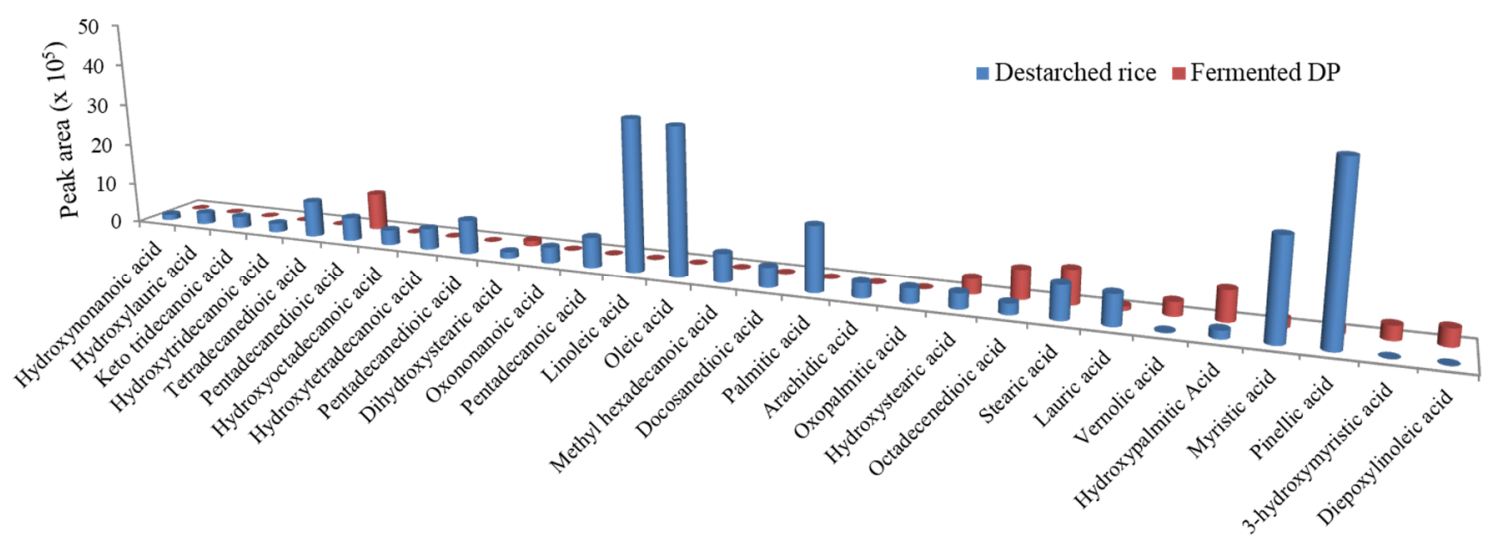

Figure 5. The relative levels of fatty acids in destarched rice and fermented DP.

\subsection{E. faecium EBD1fermented Rice Is Enriched with Antihypertensive Peptides}

Lactic acid bacteria possess cell envelop proteinases that hydrolyze proteins in media into oligopeptides after which they are absorbed to meet their nutritional needs [9]. For this reason, we analyzed the peptides generated in the fermented samples and determined their potential functions by comparing them with similar peptides already reported in literature (Table 1). In all, 32 peptides were identified in the fermented rice samples among which 16 are reported in literature as antihypertensive peptides. Nine peptides had their carboxyl or amino-terminal amino acid sequences similar to reported antihypertensive peptides, while 3 peptides, namely VPL [46], MV, and HR [47] were found to be dipeptidyl peptidase-4 (DPP IV) inhibitors. Many studies have shown the ability of DPP IV inhibitors to reduce hypertension $[48,49]$. One antioxidative peptide EL, was also found in the peptide profile of the fermented samples. The presence of these bioactive peptides in the fermented sample may contribute to the strong ACE inhibitory activity observed in this study. Meanwhile, functional analysis is required to confirm the antihypertensive activity of peptides in the fermented sample that contain sequences of already known antihypertensive peptides at their $\mathrm{C}$ and $\mathrm{N}$ terminals. Our findings are similar to other studies that reported that phenolic compounds [50,51] and bioactive peptides [52] in food can inhibit ACE activity. 
Table 1. Peptides identified in Enterococcus faecium EBD1 fermented DP.

\begin{tabular}{|c|c|c|c|c|c|c|c|c|c|}
\hline Retention Time & Peak Area & Adduct/Charge & Precursor Mass & Found at Mass & $\begin{array}{l}\text { Formula Finder } \\
\text { Results }\end{array}$ & Peptides & $\begin{array}{c}\text { Similar Peptides } \\
\text { Reported in Literature * }\end{array}$ & Peptide Function & Reference \\
\hline 0.93 & 221,600 & {$[\mathrm{M}-\mathrm{H}]-$} & 227.116 & 227.115 & C9H16N4O3 & GPG & GPG & Antihypertensive & [53] \\
\hline 0.97 & $1,227,000$ & {$[\mathrm{M}-\mathrm{H}]-$} & 516.206 & 516.2053 & C19H31N7O10 & QQQD & LQQQ & Antihypertensive & [54] \\
\hline 1.31 & 506,800 & [M-H]- & 185.058 & 185.0572 & C7H10N2O4 & EG & EG & Antihypertensive & [55] \\
\hline 3.16 & 501,500 & [M-H]- & 419.121 & 419.1206 & C18H20N4O8 & GGG & GGG & Antihypertensive & [56] \\
\hline 8.22 & 292,200 & {$[\mathrm{M}-\mathrm{H}]-$} & 442.232 & 442.2311 & C19H33N5O7 & PKEA & VDKEA & Antihypertensive & [57] \\
\hline 8.4 & 219,500 & {$[\mathrm{M}-\mathrm{H}]-$} & 426.237 & 426.2363 & C19H33N5O6 & GVGVP & Not found & - & - \\
\hline 8.63 & $2,611,000$ & {$[\mathrm{M}-\mathrm{H}]-$} & 227.105 & 227.1039 & $\mathrm{C} 10 \mathrm{H} 16 \mathrm{~N} 2 \mathrm{O} 4$ & $\mathrm{EV}$ & EV & Antihypertensive & [58] \\
\hline 9.23 & $1,306,000$ & {$[\mathrm{M}-\mathrm{H}]-$} & 291.1 & 291.0989 & $\mathrm{C} 14 \mathrm{H} 16 \mathrm{~N} 2 \mathrm{O} 5$ & EY & EY & Antihypertensive & [59] \\
\hline 9.48 & 192,900 & [M-H]- & 544.228 & 544.2266 & C23H31N9O7 & WGGGGGG & GGG & Antihypertensive & [56] \\
\hline 9.87 & 10,460 & [M-H]- & 293.116 & 293.1143 & C14H18N2O5 & DF & DF & Antihypertensive & [60] \\
\hline 10.29 & 210,900 & {$[\mathrm{M}-\mathrm{H}]-$} & 326.209 & 326.2087 & $\mathrm{C} 16 \mathrm{H} 29 \mathrm{~N} 3 \mathrm{O} 4$ & VPL & VPL & DPP IV inhibitor & [46] \\
\hline 10.6 & $1,264,000$ & {$[\mathrm{M}-\mathrm{H}]-$} & 383.231 & 383.2305 & C18H32N4O5 & PLG & PLG & Antihypertensive & [61] \\
\hline 11.56 & 195,100 & [M-H]- & 453.201 & 453.1996 & C20H30N4O8 & PDGA & Not found & - & - \\
\hline 11.61 & $3,821,000$ & {$[\mathrm{M}-\mathrm{H}]-$} & 241.121 & 241.1196 & $\mathrm{C} 11 \mathrm{H} 18 \mathrm{~N} 2 \mathrm{O} 4$ & EL & EL & Antioxidative & [62] \\
\hline 11.81 & 432,500 & [M-H]- & 489.273 & 489.2725 & C25H38N4O6 & VLPY & VLPYP & Antihypertensive & [63] \\
\hline 11.84 & 243,600 & [M-H]- & 518.227 & 518.2263 & C24H33N5O8 & DISW & ISW & Antihypertensive & [64] \\
\hline 11.91 & 478,100 & {$[\mathrm{M}-\mathrm{H}]-$} & 395.195 & 395.1941 & C18H28N4O6 & YLS & YL & Antihypertensive & [65] \\
\hline 11.92 & 267,600 & [M-H]- & 319.135 & 319.1335 & $\mathrm{C} 13 \mathrm{H} 24 \mathrm{~N} 2 \mathrm{O} 5 \mathrm{~S}$ & MG & MG & Antihypertensive & [66] \\
\hline 12.12 & 249,800 & [M-H]- & 473.209 & 473.2079 & C20H34N4O7S & EMVP & MMVPI & Antihypertensive & [67] \\
\hline 12.94 & $1,020,000$ & [M-H]- & 489.237 & 489.2361 & C24H34N4O7 & GPLA & GPL & Antihypertensive & [68] \\
\hline 13.0 & 471,200 & {$[\mathrm{M}-\mathrm{H}]-$} & 774.334 & 774.3331 & C44H49N5O6S & AW & AW & Antihypertensive & [69] \\
\hline 13.3 & 187,800 & [M-H]- & 180.974 & 180.9733 & $\mathrm{C} 2 \mathrm{H} 2 \mathrm{~N} 2 \mathrm{O} 8$ & GG & GG & Antihypertensive & [58] \\
\hline 13.41 & $1,627,000$ & {$[\mathrm{M}-\mathrm{H}]-$} & 496.316 & 496.3145 & C24H43N5O6 & IVPVA & KPVAL & Antihypertensive & [70] \\
\hline 13.42 & $1,415,000$ & [M-H]- & 528.284 & 528.2836 & C27H39N5O6 & FPIV & GPFPIIV & Antihypertensive & [70] \\
\hline 14.17 & $1,171,000$ & [M-H]- & 510.331 & 510.3303 & C25H45N5O6 & GGGGG & GGG & Antihypertensive & [56] \\
\hline 14.24 & 409,400 & {$[\mathrm{M}-\mathrm{H}]-$} & 482.263 & 482.2627 & $\mathrm{C} 22 \mathrm{H} 37 \mathrm{~N} 5 \mathrm{O} 7$ & VVPQ & VPQ & Antihypertensive & [71] \\
\hline
\end{tabular}


Table 1. Cont.

\begin{tabular}{|c|c|c|c|c|c|c|c|c|c|}
\hline Retention Time & Peak Area & Adduct/Charge & Precursor Mass & Found at Mass & $\begin{array}{l}\text { Formula Finder } \\
\text { Results }\end{array}$ & Peptides & $\begin{array}{c}\text { Similar Peptides } \\
\text { Reported in Literature * }\end{array}$ & Peptide Function & Reference \\
\hline 15.88 & 153.2 & [M-H]- & 743.35 & 743.3477 & C33H56N6O9S2 & VMV & MV & DPP IV inhibitor & [47] \\
\hline 17.11 & 14,500 & [M-H]- & 267.067 & 267.0646 & C8H16N2O6S & $\mathrm{CE}$ & Not found & - & - \\
\hline 17.22 & $1,126,000$ & [M-H]- & 310.165 & 310.1637 & $\mathrm{C} 12 \mathrm{H} 21 \mathrm{~N} 7 \mathrm{O} 3$ & HR & HR & DPP IV inhibitor & [47] \\
\hline 17.8 & 360,400 & {$[\mathrm{M}-\mathrm{H}]-$} & 457.169 & 457.1688 & C17H34N2O8S2 & $\mathrm{CC}$ & CCD & Antihypertensive & [72] \\
\hline 21.12 & 43,240 & [M-H]- & 474.264 & 474.2634 & $\mathrm{C} 22 \mathrm{H} 41 \mathrm{~N} 3 \mathrm{O} 6 \mathrm{~S}$ & ML & RML & Antihypertensive & [73] \\
\hline 22.19 & 29,960 & [M-H]- & 473.284 & 473.2837 & C19H38N8O6 & KTAR & KTAP & Antihypertensive & [63] \\
\hline
\end{tabular}

* Boldened alphabets represent amino acids sequences identified in this study and previous studies. 


\section{Conclusions}

Using untargeted metabolomics, we found that Prozyme treatment and subsequent fermentation enhanced the generation of organic acids (flavor compounds) and essential amino acids. The fermented DP samples also contained known antihypertensive phenolic compounds as well as antihypertensive peptides which make the sample a promising material for developing cheap antihypertensive foods. Despite the antihypertensive potential of the fermented product, further studies regarding the ability of Enterococcus faecium EBD1 fermented Prozyme-treated destarched rice to reduce high blood pressure in vivo is warranted.

Supplementary Materials: The following are available online at http://www.mdpi.com/2304-8158/9/8/1007/s1. Table S1: Procedure for assay of ACE activity. Table S2: Organic acids and volatile compounds in destarched rice, Prozyme treated destarched rice (DP) and fermented DP. Table S3: Amino acids in destarched rice, Prozyme treated destarched rice (DP) and fermented DP. Table S4: Phenolic compounds in destarched rice, Prozyme treated destarched rice (DP) and fermented DP.

Author Contributions: Conceptualization, E.B.-M.D. and D.-H.O.; Formal analysis, E.B.-M.D. and J.-R.K.; Investigation, F.K.O.; Methodology, R.C. and D.Y.; Resources, J.-H.K.; Supervision, D.-H.O.; Writing-original draft, E.B.-M.D. All authors have read and agreed to the published version of the manuscript.

Funding: This work was funded by the Korea Institute of Planning and Evaluation for Technology in Food, Agriculture and Forestry. Grant number 119014032SB010.

Conflicts of Interest: The authors declare that they have no conflict of interest. The funders had no role in study design, data collection and analysis, decision to publish, or preparation of the manuscript.

\section{References}

1. Zhu, F. Anthocyanins in cereals: Composition and health effects. Food Res. Int. 2018, 109, 232-249. [CrossRef] [PubMed]

2. Das, A.J.; Das, G.; Miyaji, T.; Deka, S.C. In vitro antioxidant activities of polyphenols purified from four plant species used in rice beer preparation in Assam India. Int. J. Food Prop. 2016, 19, 636-651. [CrossRef]

3. Stagos, D. Antioxidant activity of polyphenolic plant extracts. Antioxidants 2020, 9, 19. [CrossRef] [PubMed]

4. Qu, W.; Du, G.-L.; Feng, B.; Shao, H. Effects of oxidative stress on blood pressure and electrocardiogram findings in workers with occupational exposure to lead. Int. J. Med. Res. 2019, 47, 2461-2470. [CrossRef] [PubMed]

5. Montezano, A.C.; Touyz, R.M. Molecular mechanisms of hypertension-Reactive oxygen species and antioxidants: A basic science update for the clinician. Can. J. Cardiol. 2012, 28, 288-295. [CrossRef] [PubMed]

6. Alaaeddine, R.; Elkhatib, M.A.; Mroueh, A.; Fouad, H.; Saad, E.I.; El-Sabban, M.E.; Plane, F.; El-Yazbi, A.F. Impaired endothelium-dependent hyperpolarization underlies endothelial dysfunction during early metabolic challenge: Increased ROS generation and possible interference with NO function. J. Pharmacol. Exp. Ther. 2019, 371, 567-582. [CrossRef] [PubMed]

7. Mathew, E.; Mukkadan, J. Clinical disparity of oxidative stress with blood pressure. J. Biomed. Sci. $2019,3$. [CrossRef]

8. $\quad$ Kruger, R.; Schutte, R.; Huisman, H.; Van Rooyen, J.; Malan, N.; Fourie, C.; Louw, R.; Van der Westhuizen, F.; Van Deventer, C.; Malan, L. Associations between reactive oxygen species, blood pressure and arterial stiffness in black South Africans: The SABPA study. J. Hum. Hypertens. 2012, 26, 91-97. [CrossRef]

9. Daliri, E.B.-M.; Lee, B.H.; Oh, D.H. Current perspectives on antihypertensive probiotics. Probiotics Antimicrob. 2017, 9, 91-101. [CrossRef]

10. Daliri, E.B.-M.; Lee, B.H.; Oh, D.H. Current trends and perspectives of bioactive peptides. Crit. Rev. Food Sci. Nutr. 2018, 58, 2273-2284. [CrossRef]

11. Dong, J.; Xu, X.; Liang, Y.; Head, R.; Bennett, L. Inhibition of angiotensin converting enzyme activity by polyphenols from tea (Camellia sinensis) and links to processing method. Food Funct. 2011, 2, 310-319. [CrossRef] [PubMed]

12. Persson, I.A.-L.; Persson, K.; Andersson, R.G. Effect of Vaccinium myrtillus and its polyphenols on angiotensin-converting enzyme activity in human endothelial cells. J. Agric. Food Chem. 2009, 57, 4626-4629. [CrossRef] [PubMed] 
13. Al Shukor, N.; Van Camp, J.; Gonzales, G.B.; Staljanssens, D.; Struijs, K.; Zotti, M.J.; Raes, K.; Smagghe, G. Angiotensin-converting enzyme inhibitory effects by plant phenolic compounds: A study of structure activity relationships. J. Agric. Food Chem. 2013, 61, 11832-11839. [CrossRef] [PubMed]

14. Kontani, N.; Omae, R.; Kagebayashi, T.; Kaneko, K.; Yamada, Y.; Mizushige, T.; Kanamoto, R.; Ohinata, K. Characterization of Ile-His-Arg-Phe, a novel rice-derived vasorelaxing peptide with hypotensive and anorexigenic activities. Mol. Nutr. Food Res. 2014, 58, 359-364. [CrossRef] [PubMed]

15. Chen, J.; Liu, S.; Ye, R.; Cai, G.; Ji, B.; Wu, Y. Angiotensin-I converting enzyme inhibitory tripeptides from rice protein hydrolysate: Purification and characterization. J. Funct. Foods 2013, 5, 1684-1692. [CrossRef]

16. Pinciroli, M.; Aphalo, P.; Nardo, A.E.; Añón, M.C.; Quiroga, A.V. Broken rice as a potential functional ingredient with inhibitory activity of renin and angiotensin-converting enzyme. Plant Foods Hum. Nutr. 2019, 74, 405-413. [CrossRef]

17. Aluko, R.E. Antihypertensive peptides from food proteins. Annu. Rev. Food Sci. Technol. 2015, 6, $235-262$. [CrossRef]

18. Oboh, G.; Ademiluyi, A.; Akindahunsi, A. Changes in polyphenols distribution and antioxidant activity during fermentation of some underutilized legumes. Food Sci. Technol. Int. 2009, 15, 41-46. [CrossRef]

19. Rubak, Y.T.; Nuraida, L.; Iswantini, D.; Prangdimurti, E. Production of antihypertensive bioactive peptides in fermented food by lactic acid bacteria-A review. Carpath. J. Food Sci. Technol. 2019, 11, $29-44$.

20. Zhao, S.; Zhao, J.; Bu, D.; Sun, P.; Wang, J.; Dong, Z. Metabolomics analysis reveals large effect of roughage types on rumen microbial metabolic profile in dairy cows. Lett. Appl. Microbiol. 2014, 59, 79-85. [CrossRef]

21. Goldansaz, S.A.; Guo, A.C.; Sajed, T.; Steele, M.A.; Plastow, G.S.; Wishart, D.S. Livestock metabolomics and the livestock metabolome: A systematic review. PLoS ONE 2017, 12, e0177675. [CrossRef] [PubMed]

22. Yang, Y.; Dong, G.; Wang, Z.; Wang, J.; Zhang, Z.; Liu, J. Rumen and plasma metabolomics profiling by UHPLC-QTOF/MS revealed metabolic alterations associated with a high-corn diet in beef steers. PLoS ONE 2018, 13, e0208031. [CrossRef] [PubMed]

23. Metsalu, T.; Vilo, J. ClustVis: A web tool for visualizing clustering of multivariate data using principal component analysis and heatmap. Nucleic Acids Res. 2015, 43, W566-W570. [CrossRef] [PubMed]

24. Pinkard, B.R.; Gorman, D.J.; Rasmussen, E.G.; Maheshwari, V.; Kramlich, J.C.; Reinhall, P.G.; Novosselov, I.V. Raman spectroscopic data from formic acid decomposition in subcritical and supercritical water. Data Brief 2020, 29, 105312. [CrossRef] [PubMed]

25. Tung, L. Method of calculating molecular weight distribution function from gel permeation chromatograms. J. Appl. Polym. Sci. 1966, 10, 375-385. [CrossRef]

26. Berente, B.; De la Calle García, D.; Reichenbächer, M.; Danzer, K. Method development for the determination of anthocyanins in red wines by high-performance liquid chromatography and classification of German red wines by means of multivariate statistical methods. J. Chromatogr. A 2000, 871, 95-103. [CrossRef]

27. Zhou, Z.; Robards, K.; Helliwell, S.; Blanchard, C. Composition and functional properties of rice. Int. J. Food Sci. Technol. 2002, 37, 849-868. [CrossRef]

28. Suwannapan, O.; Wachirattanapongmetee, K.; Thawornchinsombut, S.; Katekaew, S. Angiotensin-Iconverting enzyme (ACE)-inhibitory peptides from Thai jasmine rice bran protein hydrolysates. Int. J. Food Sci. 2020, 55, 2441-2450. [CrossRef]

29. Cirlini, M.; Ricci, A.; Galaverna, G.; Lazzi, C. Application of lactic acid fermentation to elderberry juice: Changes in acidic and glucidic fractions. LWT Food Sci. Technol. 2020, 118, 108779. [CrossRef]

30. Wang, L.; Zhu, Q.; Lu, A.; Liu, X.; Zhang, L.; Xu, C.; Liu, X.; Li, H.; Yang, T. Sodium butyrate suppresses angiotensin II-induced hypertension by inhibition of renal (pro)renin receptor and intrarenal renin-angiotensin system. J. Hypertens. 2017, 35, 1899-1908. [CrossRef]

31. Bays, H.E.; Maccubbin, D.; Meehan, A.G.; Kuznetsova, O.; Mitchel, Y.B.; Paolini, J.F. Blood pressure-lowering effects of extended-release niacin alone and extended-release niacin/laropiprant combination: A post hoc analysis of a 24-week, placebo-controlled trial in dyslipidemic patients. Clin. Ther. 2009, 31, 115-122. [CrossRef] [PubMed]

32. Dai, T.; Chen, J.; McClements, D.J.; Hu, P.; Ye, X.; Liu, C.; Li, T. Protein-polyphenol interactions enhance the antioxidant capacity of phenolics: Analysis of rice glutelin-procyanidin dimer interactions. Food Func. 2019, 10, 765-774. [CrossRef] [PubMed] 
33. Kumar, S.; Prahalathan, P.; Raja, B. Antihypertensive and antioxidant potential of vanillic acid, a phenolic compound in L-NAME-induced hypertensive rats: A dose-dependence study. Redox Rep. 2011, 16, $208-215$. [CrossRef] [PubMed]

34. Peixoto-Neves, D.; Wang, Q.; Leal-Cardoso, J.H.; Rossoni, L.V.; Jaggar, J.H. Eugenol dilates mesenteric arteries and reduces systemic BP by activating endothelial cell TRPV 4 channels. Br. J. Pharmacol. 2015, 172, 3484-3494. [CrossRef] [PubMed]

35. Saravanakumar, M.; Raja, B. Veratric acid, a phenolic acid attenuates blood pressure and oxidative stress in L-NAME induced hypertensive rats. Eur. J. Pharmacol. 2011, 671, 87-94. [CrossRef] [PubMed]

36. Jin, L.; Piao, Z.H.; Sun, S.; Liu, B.; Kim, G.R.; Seok, Y.M.; Lin, M.Q.; Ryu, Y.; Choi, S.Y.; Kee, H.J. Gallic acid reduces blood pressure and attenuates oxidative stress and cardiac hypertrophy in spontaneously hypertensive rats. Sci. Rep. 2017, 7, 1-14. [CrossRef]

37. Luo, D.; Xu, J.; Chen, X.; Zhu, X.; Liu, S.; Li, J.; Xu, X.; Ma, X.; Zhao, J.; Ji, X. (-)-Epigallocatechin-3-gallate (EGCG) attenuates salt-induced hypertension and renal injury in Dahl salt-sensitive rats. Sci. Rep. 2020, 10, 1-11. [CrossRef]

38. Sui, H.; Yan, W. Effect of apigenin on SBP of spontaneous hypertension rats and its mechanism. J. Environ. Health 2009, 26, 112-113.

39. Yusuf, M.A.; Singh, B.N.; Sudheer, S.; Kharwar, R.N.; Siddiqui, S.; Abdel-Azeem, A.M.; Fernandes Fraceto, L.; Dashora, K.; Gupta, V.K. Chrysophanol: A natural anthraquinone with multifaceted biotherapeutic potential. Biomolecules 2019, 9, 68.

40. Chandrasekara, A.; Shahidi, F. Bioaccessibility and antioxidant potential of millet grain phenolics as affected by simulated in vitro digestion and microbial fermentation. J. Funct. Foods 2012, 4, 226-237. [CrossRef]

41. Dey, T.B.; Kuhad, R.C. Enhanced production and extraction of phenolic compounds from wheat by solid-state fermentation with Rhizopus oryzae RCK2012. Biotech. Rep. 2014, 4, 120-127.

42. Liptáková, D.; Matejčeková, Z.; Valík, L. Lactic acid bacteria and fermentation of cereals and pseudocereals. Ferment. Process. 2017, 10, 65459.

43. Wang, Z.J.; Liang, C.L.; Li, G.M.; Yu, C.Y.; Yin, M. Stearic acid protects primary cultured cortical neurons against oxidative stress4. Acta Pharmacol. Sin. 2007, 28, 315-326. [CrossRef]

44. Alves, N.F.B.; de Queiroz, T.M.; de Almeida Travassos, R.; Magnani, M.; de Andrade Braga, V. Acute treatment with lauric acid reduces blood pressure and oxidative stress in spontaneously hypertensive rats. Basic Clin. Pharmacol. Toxicol. 2017, 120, 348-353. [CrossRef] [PubMed]

45. Antony, U.; Sripriya, G.; Chandra, T. The effect of fermentation on the primary nutrients in foxtail millet (Setaria italica). Food Chem. 1996, 56, 381-384. [CrossRef]

46. Umezawa, H.; Aoyagi, T.; Ogawa, K.; Naganawa, H.; Hamada, M.; Takeuchi, T. Diprotins A and B, inhibitors of dipeptidyl aminopeptidase IV, produced by bacteria. J. Antibiot. 1984, 37, 422-425. [CrossRef]

47. Lan, V.T.T.; Ito, K.; Ohno, M.; Motoyama, T.; Ito, S.; Kawarasaki, Y. Analyzing a dipeptide library to identify human dipeptidyl peptidase IV inhibitor. Food Chem. 2015, 175, 66-73. [CrossRef] [PubMed]

48. Cosenso-Martin, L.N.; Giollo-Junior, L.T.; Vilela-Martin, J.F. DPP-4 inhibitor reduces central blood pressure in a diabetic and hypertensive patient: A case report. Medicine 2015, 94. [CrossRef]

49. Pacheco, B.P.; Crajoinas, R.O.; Couto, G.K.; Davel, A.P.C.; Lessa, L.M.; Rossoni, L.V.; Girardi, A.C. Dipeptidyl peptidase IV inhibition attenuates blood pressure rising in young spontaneously hypertensive rats. Int. J. Hypertens. 2011, 29, 520-528. [CrossRef]

50. Zhang, Y.; Pechan, T.; Chang, S.K.C. Antioxidant and angiotensin-I converting enzyme inhibitory activities of phenolic extracts and fractions derived from three phenolic-rich legume varieties. J. Funct. Foods 2018, 42, 289-297. [CrossRef]

51. Santos, M.C.; Toson, N.S.B.; Pimentel, M.C.B.; Bordignon, S.A.L.; Mendez, A.S.L.; Henriques, A.T. Polyphenols composition from leaves of Cuphea spp. and inhibitor potential, in vitro, of angiotensin I-converting enzyme (ACE). J. Ethnopharmacol. 2020, 255, 112781. [CrossRef] [PubMed]

52. Wang, X.; Chen, H.; Fu, X.; Li, S.; Wei, J. A novel antioxidant and ACE inhibitory peptide from rice bran protein: Biochemical characterization and molecular docking study. LWT Food Sci. Technol. 2017, 75, 93-99. [CrossRef]

53. Wang, X.; Wang, J.; Lin, Y.; Ding, Y.; Wang, Y.; Cheng, X.; Lin, Z. QSAR study on angiotensin-converting enzyme inhibitor oligopeptides based on a novel set of sequence information descriptors. J. Mol. Model. 2011, 17, 1599-1606. [CrossRef] [PubMed] 
54. Yano, S.; Suzuki, K.; Funatsu, G. Isolation from $\alpha$-zein of thermolysin peptides with angiotensin I-converting enzyme inhibitory activity. Biosci. Biotechnol. Biochem. 1996, 60, 661-663. [CrossRef] [PubMed]

55. Cheung, H.-S.; Wang, F.-L.; Ondetti, M.A.; Sabo, E.F.; Cushman, D.W. Binding of peptide substrates and inhibitors of angiotensin-converting enzyme. Importance of the $\mathrm{COOH}$-terminal dipeptide sequence. J. Biol. Chem. 1980, 255, 401-407. [PubMed]

56. Zhou, P.; Yang, C.; Ren, Y.; Wang, C.; Tian, F. What are the ideal properties for functional food peptides with antihypertensive effect? A computational peptidology approach. Food Chem. 2013, 141, 2967-2973. [CrossRef] [PubMed]

57. Hernández-Ledesma, B.; Recio, I.; Ramos, M.; Amigo, L. Preparation of ovine and caprine $\beta$-lactoglobulin hydrolysates with ACE-inhibitory activity. Identification of active peptides from caprine $\beta$-lactoglobulin hydrolysed with thermolysin. Int. Dairy J. 2002, 12, 805-812. [CrossRef]

58. Castellano, P.; Aristoy, M.-C.; Sentandreu, M.Á.; Vignolo, G.; Toldrá, F. Peptides with angiotensin I converting enzyme (ACE) inhibitory activity generated from porcine skeletal muscle proteins by the action of meat-borne Lactobacillus. J. Proteom. 2013, 89, 183-190. [CrossRef]

59. Wu, H.; He, H.-L.; Chen, X.-L.; Sun, C.-Y.; Zhang, Y.-Z.; Zhou, B.-C. Purification and identification of novel angiotensin-I-converting enzyme inhibitory peptides from shark meat hydrolysate. Process Biochem. 2008, 43, 457-461. [CrossRef]

60. Ichimura, T.; Hu, J.; Aita, D.Q.; Maruyama, S. Angiotensin I-converting enzyme inhibitory activity and insulin secretion stimulative activity of fermented fish sauce. J. Biosci. Bioeng. 2003, 96, 496-499. [CrossRef]

61. Byun, H.-G.; Kim, S.-K. Structure and activity of angiotensin I converting enzyme inhibitory peptides derived from Alaskan pollack skin. BMB Rep. 2002, 35, 239-243. [CrossRef] [PubMed]

62. Suetsuna, K.; Ukeda, H.; Ochi, H. Isolation and characterization of free radical scavenging activities peptides derived from casein. J. Nutr. Biochem. 2000, 11, 128-131. [CrossRef]

63. Kohmura, M.; Nio, N.; Kubo, K.; Minoshima, Y.; Munekata, E.; Ariyoshi, Y. Inhibition of angiotensin-converting enzyme by synthetic peptides of human $\beta$-casein. Agric. Biol. Chem. 1989, 53, 2107-2114.

64. Gu, Y.; Majumder, K.; Wu, J. QSAR-aided in silico approach in evaluation of food proteins as precursors of ACE inhibitory peptides. Food Res. Int. 2011, 44, 2465-2474. [CrossRef]

65. Tauzin, J.; Miclo, L.; Gaillard, J.-L. Angiotensin-I-converting enzyme inhibitory peptides from tryptic hydrolysate of bovine $\alpha$ S2-casein. FEBS Lett. 2002, 531, 369-374. [CrossRef]

66. Nogata, Y.; Nagamine, T.; Yanaka, M.; Ohta, H. Angiotensin I converting enzyme inhibitory peptides produced by autolysis reactions from wheat bran. J. Agric. Food Chem. 2009, 57, 6618-6622. [CrossRef]

67. Escudero, E.; Sentandreu, M.A.; Arihara, K.; Toldra, F. Angiotensin I-converting enzyme inhibitory peptides generated from in vitro gastrointestinal digestion of pork meat. J. Agric. Food Chem. 2010, 58, 2895-2901. [CrossRef]

68. He, R.; Malomo, S.A.; Girgih, A.T.; Ju, X.; Aluko, R.E. Glycinyl-histidinyl-serine (GHS), a novel rapeseed protein-derived peptide has blood pressure-lowering effect in spontaneously hypertensive rats. J. Agric. Food Chem. 2013, 61, 8396-8402. [CrossRef]

69. Nakahara, T.; Sano, A.; Yamaguchi, H.; Sugimoto, K.; Chikata, H.; Kinoshita, E.; Uchida, R. Antihypertensive effect of peptide-enriched soy sauce-like seasoning and identification of its angiotensin I-converting enzyme inhibitory substances. J. Agric. Food Chem. 2010, 58, 821-827. [CrossRef]

70. Del Mar Contreras, M.; Carrón, R.; Montero, M.J.; Ramos, M.; Recio, I. Novel casein-derived peptides with antihypertensive activity. Int. Dairy J. 2009, 19, 566-573. [CrossRef]

71. Minervini, F.; Algaron, F.; Rizzello, C.; Fox, P.; Monnet, V.; Gobbetti, M. Angiotensin I-convertingenzyme-inhibitory and antibacterial peptides from Lactobacillus helveticus PR4 proteinase-hydrolyzed caseins of milk from six species. Appl. Environ. Microbiol. 2003, 69, 5297-5305. [CrossRef] [PubMed] 
72. Udenigwe, C.C.; Adebiyi, A.P.; Doyen, A.; Li, H.; Bazinet, L.; Aluko, R.E. Low molecular weight flaxseed protein-derived arginine-containing peptides reduced blood pressure of spontaneously hypertensive rats faster than amino acid form of arginine and native flaxseed protein. Food Chem. 2012, 132, 468-475. [CrossRef] [PubMed]

73. Wu, J.; Aluko, R.E.; Nakai, S. Structural requirements of angiotensin I-converting enzyme inhibitory peptides: Quantitative structure- activity relationship study of di-and tripeptides. J. Agric. Food Chem. 2006, 54, 732-738. [CrossRef] [PubMed]

C 2020 by the authors. Licensee MDPI, Basel, Switzerland. This article is an open access article distributed under the terms and conditions of the Creative Commons Attribution (CC BY) license (http://creativecommons.org/licenses/by/4.0/). 